\title{
Clinical and histopathological study of brooder pneumonia in broiler farms
}

\author{
N.R.Abdulrahman N.M. Saeed S.F. Muhammad \\ Coll. of Vet. Med. Univ. of Sulaimania
}

\begin{abstract}
The outbreaks of aspergillosis in broiler chicks (4-15 days old) were observed from January to July, 2011 in five broiler farms. The disease was detected on the basis of clinical signs, gross, histopathological and cultural findings. Infected chicks showed signs of ruffled feathers, green watery diarrhea, anorexia, gasping and dyspnea. On examination, numerous small white yellowish nodules were seen in the lungs, air sacs, kidneys, thoracic wall and abdominal serosa. Microscopically the lungs revealed granulomas with central areas of caseation surrounded by heterophils and giant cells. Aspergillus fumigatus could be isolated in Sabouraud's dextrose agar from the lesions. Higher morbidity (76 to 100\%) and mortality $(62.5$ to $100 \%)$ rates were recorded in the five farms. This is the first record on the occurrence of acute aspergillosis in broiler chicks from Sulaimania/ Iraq.
\end{abstract}

Key words: Acute aspergillosis, Broiler chicks, Brooder pneumonia

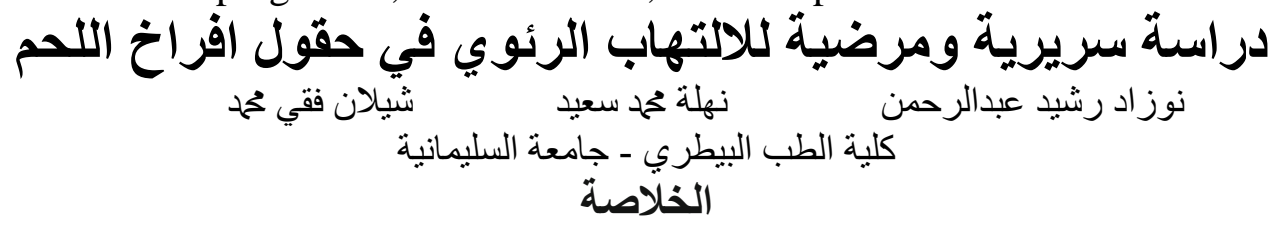

لوحظ حدوث اندلاع لاء الرشاثشيات في خمسة حقول لافر اخ اللحم بعمر (4-15 يومان) من كانون الثاني إلى تموز

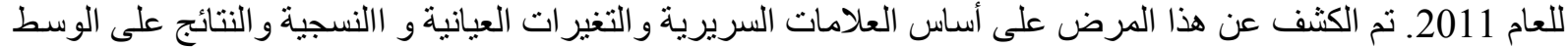

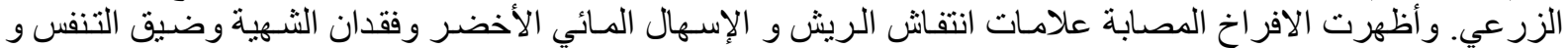

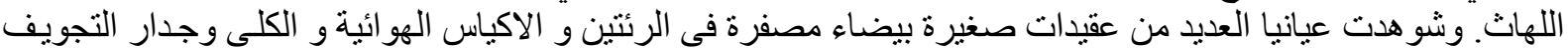

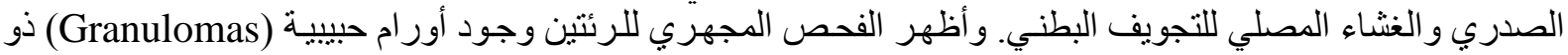

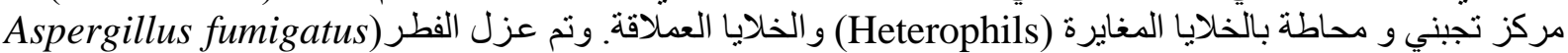

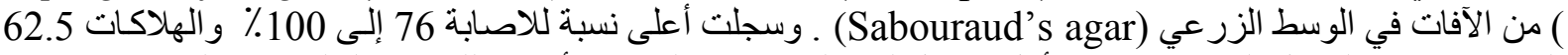

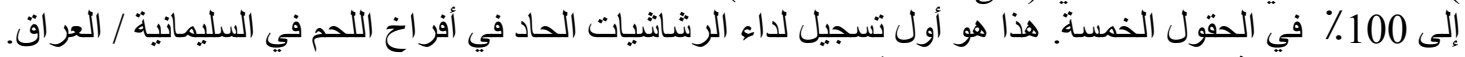

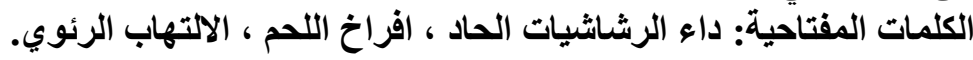

\section{Introduction}

In the early 1800 s, moulds, probably belonging to the genus Aspergillus, were described in wild birds in Europe. Since then aspergillosis has been described worldwide in a very large number of avian species and probably all birds are susceptible to infection (1and 2).Aspergillosis in birds is usually confined to the lower pulmonary system with florid lesions in air sacs and lungs. It is an infectious, non-contagious fungal disease caused by species in the ubiquitous opportunistic saprophytic genus Aspergillus, in particular Aspergillus fumigatus (3). Aspergillus spores are commonly found in air, water, soil, plant debris, rotten vegetation, manure, sawdust litter, biogases litter, animal feed, on animals and indoor air environment (4 and 5).In poultry, a severe acute form has been observed mostly in young subjects, with high morbidity and mortality rates, and a chronic form in adult subjects, especially in turkey breeders (6 and $7)$. Infection results in so called brooder pneumonia. Infected birds often show no clinical signs; however, dyspnea, gasping, or accelerated breathing can occur (8). The target organs are the lungs and the air sacs, but in their systemic forms they can also affect the liver, the kidney, the encephalon, the bones, the skin and the eyes (9).Histopathologically, the lesions are characterized by two different patterns: a granulomatous form with internally-septate hyphae that typically develop into non-aerate parenchyma, and a non-encapsulated diffuse form, containing sporangia with a typical 
morphology located in the lung or even more frequently in the air sacs (10).

\section{Materials and methods}

\section{Sample collection}

This study was conducted to diagnose aspergillosis in broiler during the physical visit of the farms and when submitted to microbiology and pathology Laboratory of veterinary medicine college / Sulaimania university. A total of 5 incidences of aspergillosis in broiler farms, were detected during January to July, 2011.The flock history including types of birds (Ross-308), population of birds per flock, age of birds, morbidity, and mortality (Table 1). The clinical signs of the affected flocks were recorded during the physical visit of the flocks and the farmer's complaints in connection to it was also considered and noted.

Table 1: Clinical history of the different flocks examined

\begin{tabular}{|c|c|c|c|c|c|c|}
\hline $\begin{array}{l}\text { Farms } \\
\text { name }\end{array}$ & Location & $\begin{array}{l}\text { Age of } \\
\text { birds } \\
\text { (Days) }\end{array}$ & $\begin{array}{l}\text { Population } \\
\text { Birds/flock }\end{array}$ & $\begin{array}{l}\text { Morbidity } \\
\text { rate } \\
\text { /flock }\end{array}$ & $\begin{array}{c}\text { Mortality } \\
\text { rate } \\
\text { /flock }\end{array}$ & $\begin{array}{c}\text { Types of } \\
\text { Birds }\end{array}$ \\
\hline Sawin & Ranya & 4 & 10000 & $100 \%$ & $100 \%$ & \multirow{5}{*}{ Ross-308 } \\
\hline Ayanda & Kalar & 15 & 8000 & $80 \%$ & 62.5 & \\
\hline Kuzhin & Bazyan & 14 & 12000 & $76 \%$ & 63.3 & \\
\hline Zryan & Bazyan & 5 & 11000 & $90 \%$ & 81.82 & \\
\hline$\overline{\text { Azad }}$ & Kalar & 5 & 6000 & $100 \%$ & $100 \%$ & \\
\hline
\end{tabular}

\section{Necropsy and histopathological examin- ation:}

Both sick and dead birds submitted for diagnosis were examined systematically at necropsy following standard procedure (11). The birds were also brought to laboratory during physical visit for detailed examinations. The clinical history and signs were carefully considered before the attempt of postmortem examination. The physical appearances of the carcasses and the visible gross morbid lesions of the organs and tissues were recorded. The tissue samples (Lungs) were collected during the course of necropsy and preserved at $10 \%$ buffered formalin. Following trimming and blocking in paraffin 5-6 micrometer thick cross sections were prepared and stained with hematoxylin / eosin and PAS (12).

\section{Isolation and Identification:}

The isolation of Aspergillus fumigatus was carried from affected organs (Lungs, air sacs and liver) of morbid birds. These samples were directly streaked on Sabouraud dextrose agar plates for culturing and were incubated for 3 days at $37{ }^{\circ} \mathrm{C}$. Aspergillus fumigatus was identified according to its specific colony characteristics, slides were also prepared for identification of mycelium and hyphae arrangement with lactophenol blue staining method (13).

\section{Results}

\section{Clinical signs:}

General clinical signs (ruffled feathers, green watery diarrhea and anorexia) and respiratory tract (gasping and dyspnea) referring to aspergillosis was observed (Fig.1).

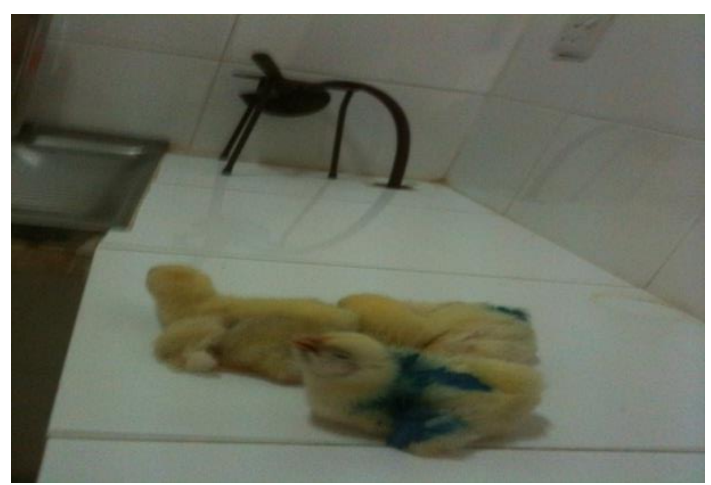

Fig.(1) chick shows signs of gasping and dyspnea 


\section{Gross lesions:}

Necropsies of chicks which died revealed the presence of white-yellowish caseous nodules in the lungs, air sacs,

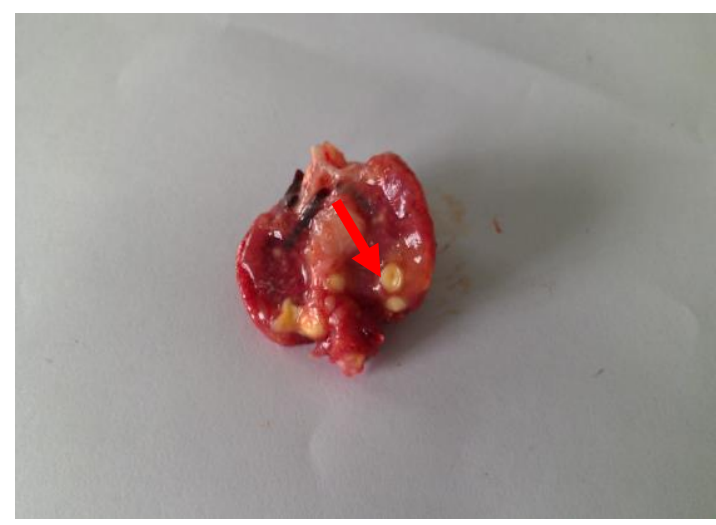

Fig.(2) white-yellowish caseous nodules in the lung

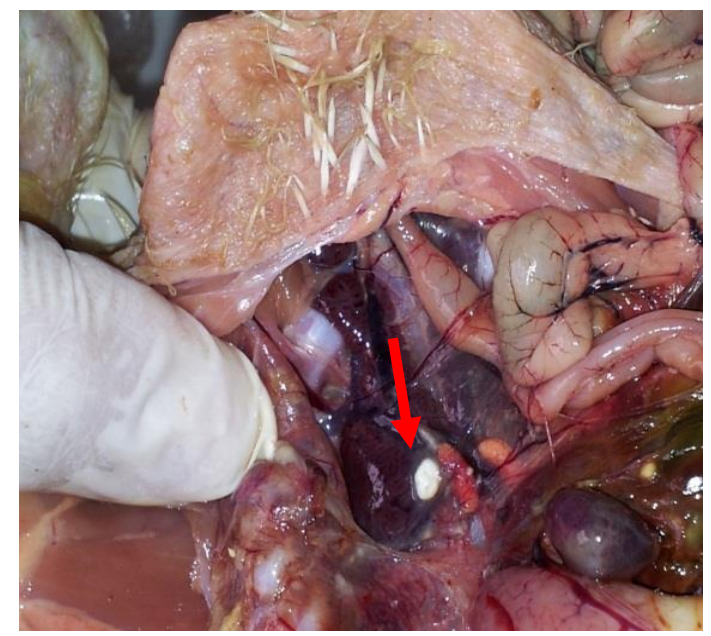

Fig.(4) white-yellowish caseous nodules in the kidney

\section{Histopathological lesions:}

Histopathological examination of lungs revealed granulomas with eosinophilic necrotic centers surrounded by giant cells and scattered heterophils (Fig .6)Aspergillus kidney, thoracic wall and abdominal serosa ranging from pin point to chickpea in size (Fig.2, 3, 4 and 5).

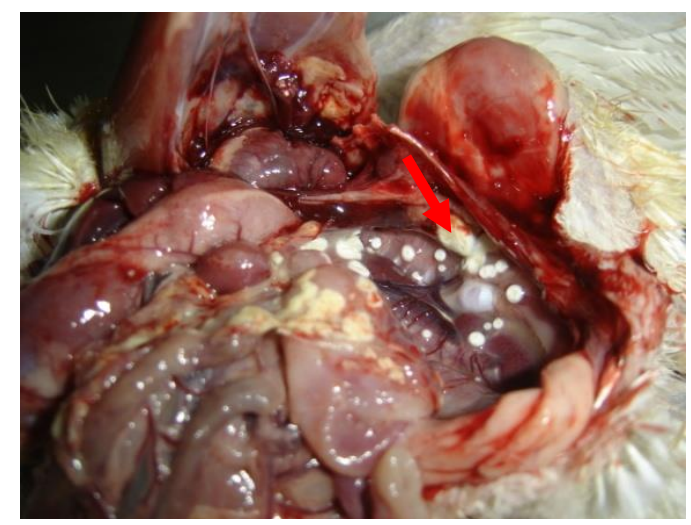

Fig. (3) white-yellowish caseous nodules on the air sacs

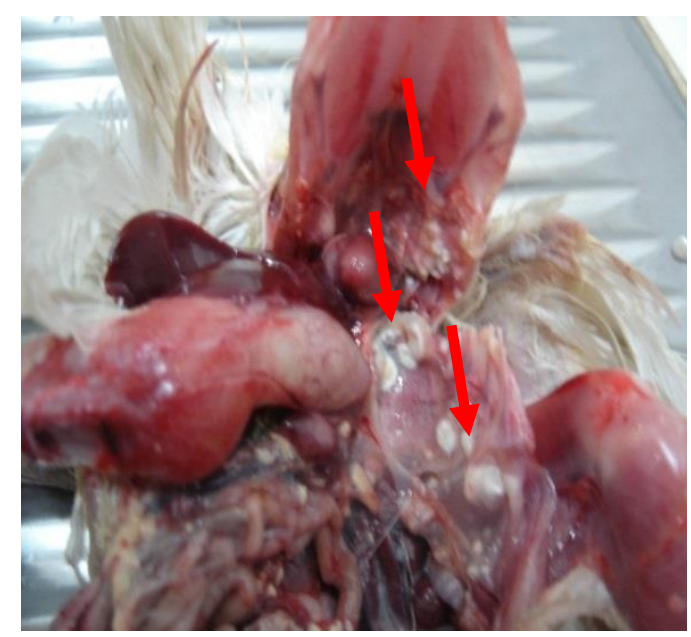

Fig.(5) white-yellowish caseous nodules on the thoracic wall and abdominal serosa

hyphae also were observed in stained sections prepared from lesioned organs by PAS staining procedure. Fungal spores and branched septate hyphae were observed in this direct microscopy (Fig.7). 


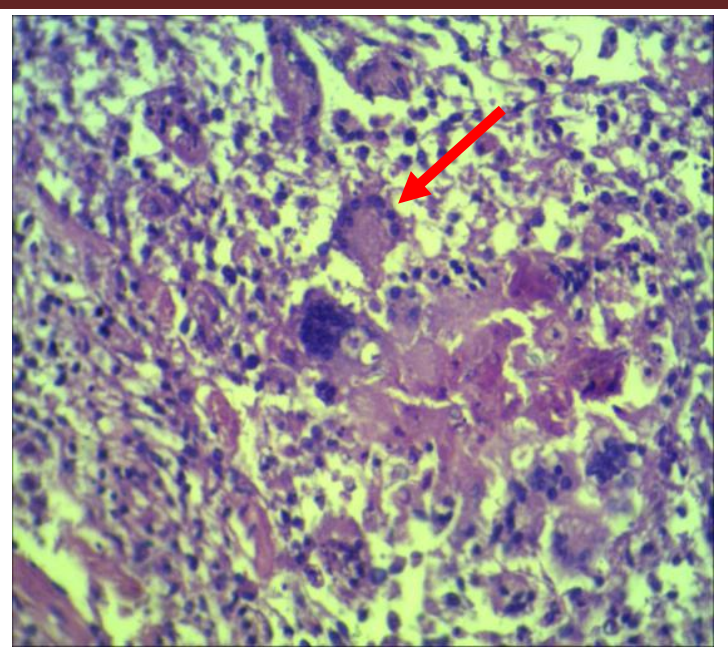

b

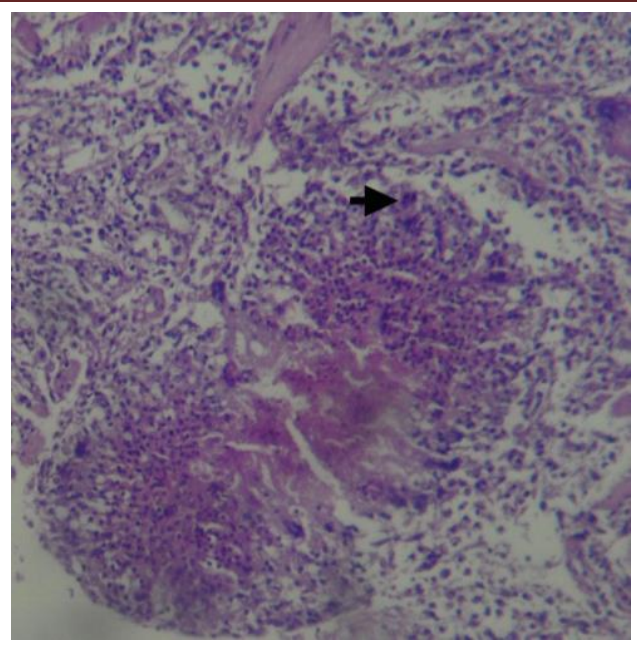

Fig.(6) Aspergillus granuloma with a central eosinophilic necrosis surrounded by foreign-body giant cells $(a=H \& E$ 100X), scattered heterophils $(b=H \& E$ 40X).

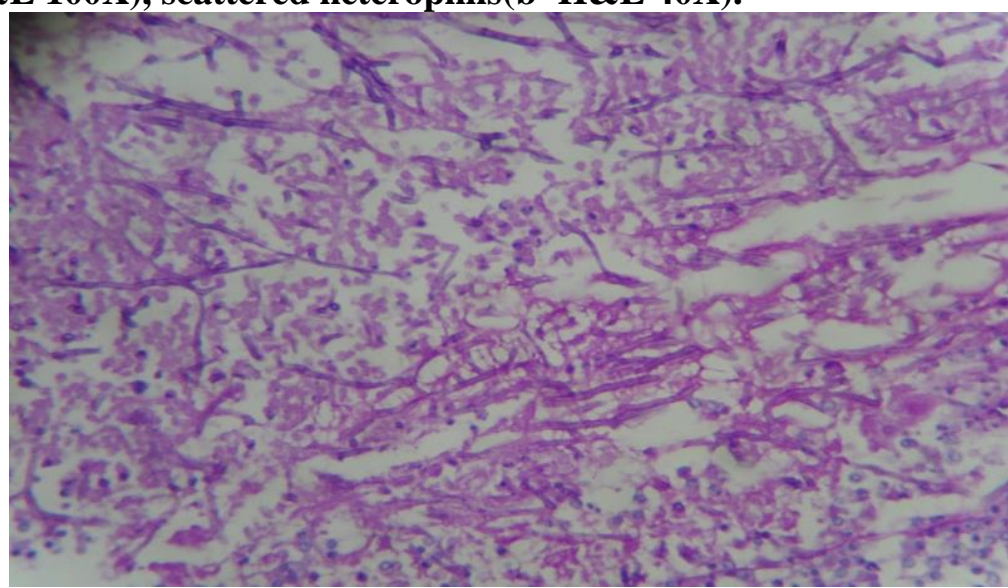

Fig.(7) Fungal spores and grown Hyphae could be observed among the inflammatory necrotic masses (PAS, 100X).

\section{Cultural investigation:}

On the third day post incubation, gross examination shows grey whitish colonies (Fig.8) and microscopic examination of

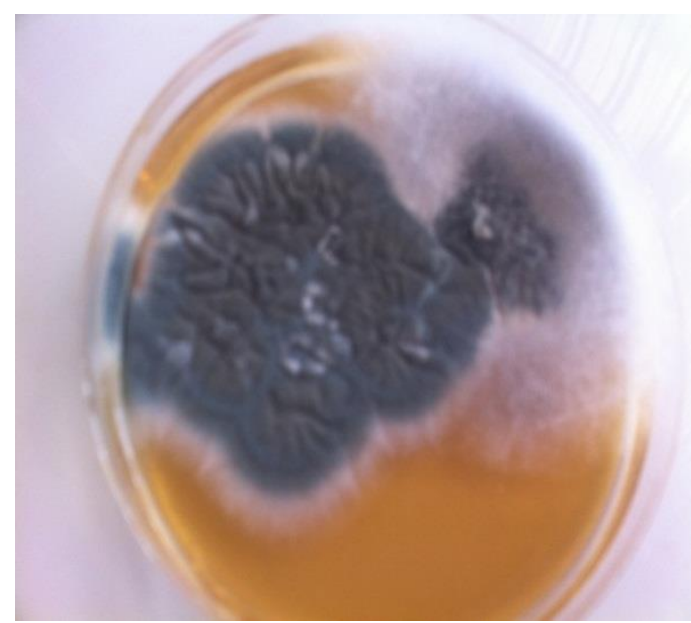

Fig.(8) grey whitish colonies preparation made from these colonies revealed conidiophores with sphere-shaped or semispherical conidia (Fig.9).

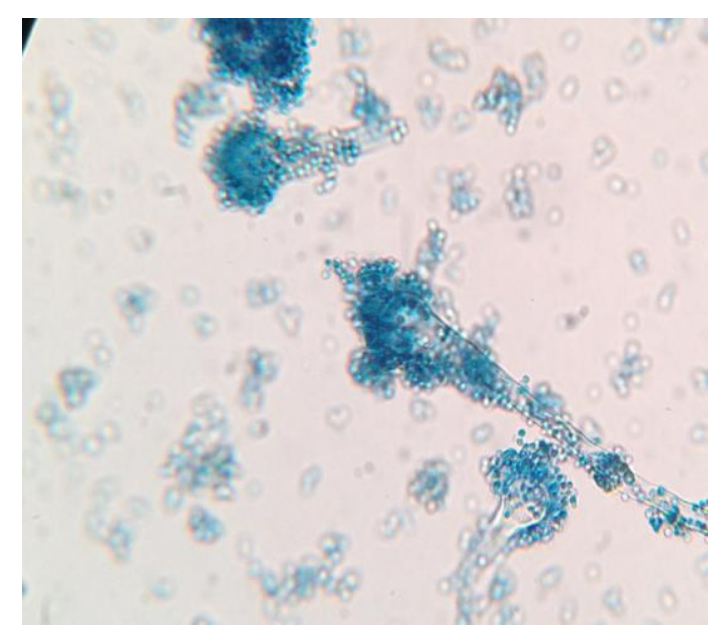

Fig.(9) conidiophores with sphere-shaped or semispherical conidia(Lactophenol cotton blue staining) 


\section{Discussion}

Aspergillosis in commercial broiler was investigated based on clinical, pathological and cultural findings. The disease was diagnosed on the basis of clinical signs, necropsy findings, histopathological examinations and detection of etiological agent on selective media. Aspergillosis is a mycotic infection primarily of chickens. The age of infection to aspergillus in this study varied from flock to flock. However, birds with different age group are susceptible to aspergillus infection reported elsewhere (8). Clinical signs such as dyspnea, gasping, cyanosis, and hyperpnea are usually associated with aspergillosis (1). In the present study signs resembling respiratory

\section{References}

1. Richard, J.L. (1997).Aspergillosis. In: Diseases of poultry. Calnek, B. W. ; Barnes, H. J. ; Beard, C. W. ; Reid, W. M. and Yoder, Jr., H. W. (Ed) $10^{\text {th }}$ ed. Iowa State University Press, Ames, IA. PP: 351-360.

2. Tell, L.A. (2005). Aspergillosis in mammals and birds: impact in veterinary medicine. Medical Mycology, 43: 71-73.

3. Beernaert, L. A.; Pasmans, F.; Van Waeyenberghe, L.; Haesebrouck, F. and Martel, A.(2010). Aspergillus infections in birds: a review. Avian Pathology, 39(5), 325-331.

4. Pattron, D.D.(2006).Aspergillus, health implication $\&$ recommendations for public health food safety. Internet Journal of Food Safety, 8:19-23.

5. Perdelli, F; Sartini, M; Spagnolo, A.M.; Dallera, M.; Lombardi, R. and Cristina, M.L.( 2006). A problem of hospital hygiene: the presence of aspergilli in hospital wards with different airconditioning features. Am. J. Infect. Control.34 (5):264-8.

6. Radkowski, M.; Uradziński, J and Szteyn, J. (1996).The occurrence of infectious and parasitic diseases in poultry slaughtered in the district of Olsztyn, Poland, 1986-91. Avian Dis.; 40 (2):2859.

7. Martin, M.P.; Bouck, K.P.; Helm, J.; Dykstra, M.J.; Wages, D.P and Barnes, H.J. (2007).Disseminated aspergillus flavus infection in broiler breeder pullets. Avian Dis. 51(2):626-31.

8. Charlton, B.R.; Chin, R. P. and Barnes, H. J. (2008).Fungal infections. In: Diseases of poultry. Saif, Y. M.; Fadly, A. M. ; Glisson, J. R. ; disease were observed. In the present study it was observed that the disease is occurring in young birds. This finding is also in agreement with those (14) and (15) who reported that aspergillosis with respect to age was high in younger ages. The lesions of granulomatous nodules are commonly confined to lungs and air sacs. Our result is in line with the finding of (1) and (8) who reported that lesions in birds are commonly confined to lungs and air sacs. Histopathological changes of lungs showed granulomas with eosinophilic necrotic centers surrounded by giant cells and scattered heterophils. These findings were described elsewhere (16).

McDougald, L. R.; Nolan, L. K.; and Swayne, D. E. (Ed) $12^{\text {th }}$ ed. Iowa State Press, Ames, Iowa. PP: 989-1008.

9. Raja, N.S. and Singh, N.N. (2006).Disseminated invasive aspergillosis in an apparently immunocompetent host. J Microbiol Immunol Infect. 39(1):73-7.

10. Nardoni, S.; Ceccherelli, R.; Rossi, G. and Mancianti, F. (2006). Aspergillosis in Larus cachinnans micaellis: survey of eight cases. Mycopathologia, 161(5):317-21.

11. Charlton, B.R. (2000). Fungal Diseases. In: Avian Disease Manual. 5th ed. The American Association of Avian Pathologists. U.S.A.

12. Luna, L.G. (1968). Manual of Histologic Staining Methods of the Armed Forces Institute of Animals, 3rd ed. McGraw-Hill Book Company. New York.

13. Karunakaran, S.; Nair, G.K.; Nair, N. D. and Mini.M. (2010). Systemic Aspergillosis in Emu Chicks in an organised farm in Kerala. Veterinary World.3 (10):453-455.

14. Sing, J. and Malhotra, F. C.(1980).Experimental studies on Aspergillosis in chicks. Veterinary bulletin, 49: 5279.

15. Sajid, M. A.; Khan, I. A. and Rauf, U. (2006). Aspergillus fumigatus in commercial poultry flocks, a serious threat to poultry industry in Pakistan. J. Anim. Poul. Sci. 16(3-4).

16. Islami, M. N.; Rashid, S. M. H.; Juli, M. S. B. ; Rima, U. K. AND Khatun, M. (2009). Pneumomycosis in chickens: Clinical, Pathological and thrapeutical investigation. Int. J. Sustain. Crop Prod. 4(3):16-21 